\title{
IDENTIFIKASI PENYAKIT PADA BIBIT JELUTUNG (Dyera costulata Hook. F) DI PERSEMAIAN
}

\author{
Identification of Diseases on Jelutung (Dyera costulata Hook.F) in Nursery \\ Sri Utami, Asmaliyah dan/and Hengki Siahaan \\ Balai Penelitian Kehutanan Palembang \\ Jl. Kol. Burlian KM 6,5 Puntikayu, Palembang \\ Telp./Fax. (0711) 414864
}

Naskah masuk : 11 Pebruari 2008 ; Naskah diterima : 18 Nopember 2008

\begin{abstract}
Disease is one problem of jelutung (Dyera costulata Hook.F) seedling. The research was conducted at Nursery of Forestry Research Institute Palembang, South Sumatra aimed to invent, identify the disease and observed the environmental factors. The results showed that jelutung seedlings were attacked by Pyrenochaeta sp. The disease identified leaf spot disease. The severity of disease was affected by environmental factors.
\end{abstract}

Key words: Dyera costulata, Pyrenochaeta sp., leaf spot disease

\begin{abstract}
ABSTRAK
Penyakit merupakan salah satu permasalahan dalam pembibitan jelutung (Dyera costulata Hook.f). Penelitian ini dilakukan di persemaian Balai Penelitian Kehutanan Palembang, Sumatera Selatan yang bertujuan untuk menginventarisasi jenis penyakit, mengidentifikasi jenis patogen penyebab penyakit dan faktor yang mendukung timbul dan berkembangnya penyakit tersebut. Hasil penelitian menunjukkan bahwa bibit jelutung terserang patogen Pyrenochaeta sp. Jenis penyakit yang menyerang bibit jelutung yaitu bercak daun. Faktor-faktor yang mempengaruhi timbul dan berkembangnya penyakit tersebut yaitu faktor lingkungan fisik.
\end{abstract}

Kata kunci : Dyera costulata, Pyrenochaeta sp., penyakit bercak daun

\section{PENDAHULUAN}

\section{A. Latar Belakang}

Jelutung (Dyera costulata Hook.f) merupakan jenis pohon lokal (indigenous species) yang mempunyai banyak kegunaan dan potensi untuk dikembangkan. Pohon jelutung menghasilkan kayu yang berkualitas tinggi dan bernilai ekonomis. Getahnya mempunyai nilai ekonomi tinggi sebagai komoditi ekspor. Pada tahun 1987, Indonesia mampu mengekspor jelutung sebesar $32.589 \mathrm{~m}^{3}$ yang setara dengan 2.183.462 US\$ (Anonim, 1995). Selain getah, rambut akar (folides) seringkali dipakai untuk obor dan penolak nyamuk (Lemmens et al., 1995). Penyebaran jenis ini secara alami terdapat di Sumatera dan Kalimantan. Pada awalnya jelutung merupakan jenis yang banyak dijumpai di wilayah Sumatera Bagian Selatan. Namun saat ini telah menjadi langka dan hanya dijumpai secara sporadis pada beberapa lokasi di Jambi dan Sumatera Selatan. Jenis ini menjadi langka akibat tingginya tingkat 
eksploitasi yang dilakukan oleh masyarakat maupun perusahaan yang bergerak di bidang kehutanan tanpa diimbangi dengan kegiatan budidaya (Siahaan et al., 2005).

Berdasarkan kondisi tersebut maka perlu adanya upaya pembangunan hutan tanaman jelutung. Pembibitan merupakan langkah awal yang sangat penting dalam pembangunan hutan tanaman karena akan menentukan kualitas tanaman yang dihasilkan. Beberapa faktor yang menentukan keberhasilan pembibitan adalah penggunaan bibit yang bermutu (tidak terserang penyakit), pemilihan media sapih, serta jenis dan dosis pupuk yang tepat.

Kenyataan di lapangan seringkali dijumpai adanya serangan penyakit di persemaian, seperti yang saat ini terjadi pada jelutung. Serangan penyakit dapat menyebabkan kegagalan dalam pembibitan apabila tidak segera dilakukan pengendalian. Kegiatan pengendalian akan berhasil apabila jenis patogen, status dan bioekologinya diketahui, oleh karena itu informasi dan pengetahuan tentang jenis patogen, faktor yang mendukung timbul dan berkembangnya penyakit, penyebaran dan kerusakan yang ditimbulkannya sangat diperlukan untuk menjamin keberhasilan pembibitan jelutung.

\section{B. Tujuan}

Penelitian ini bertujuan untuk menginventarisasi jenis penyakit, mengidentifikasi jenis patogen penyebab penyakit dan faktor yang mendukung timbul dan berkembangnya penyakit tersebut. Informasi dan pengetahuan yang diperoleh diharapkan menjadi bahan acuan dalam upaya pencegahan dan pengendaliannya.

\section{BAHAN DAN METODE}

\section{A. Tempat dan Waktu}

Penelitian dilaksanakan di persemaian Balai Penelitian Kehutanan Palembang pada bulan Agustus sampai Desember 2006.

\section{B. Bahan dan Alat}

Bahan yang digunakan untuk penelitian adalah bibit jelutung berumur 4 bulan, media agarkentang (PDA/Potatoes Dextrose Agar), alkohol 70\%, aquades steril, spiritus, kertas saring, kertas tissue, kertas label, kapas, kantong plastik, alumunium foil, dan kertas koran. Alat-alat yang digunakan untuk penelitian adalah termo-hygrometer, hand counter, loupe, cawan petri, labu erlenmeyer, pinset, pisau, jarum ose, lampu bunsen, gelas obyek, kaca penutup, blender, alat pengaduk, oven, autoklaf, kamera, Laminar Air Flow (LAF), serta alat tulis (pulpen dan spidol).

\section{Metode}

1. Pengambilan Data

Pengambilan data dilakukan dengan mengamati bibit jelutung yang berumur 4 bulan di persemaian, baik yang terserang atau tidak terserang penyakit. Jumlah sampel yang diamati sebanyak 288 bibit.

\section{Parameter Pengamatan}

Parameter yang diamati adalah gejala, persentase dan intensitas serangan penyakit pada bibit jelutung yang berumur 4 bulan. Penghitungan persentase serangan dilakukan dengan membandingkan jumlah tanaman yang terserang dengan jumlah seluruh tanaman yang ada pada setiap petak, yang dinyatakan dalam persen (\%). 
Persentase Serangan $=\frac{\text { Jumlah tanaman terserang penyakit }}{\text { Jumlah seluruh tanaman }} \times 100 \%$

Penghitungan intensitas serangan dilakukan dengan rumus sebagai berikut :

$\mathrm{I}=\frac{\sum(\mathrm{ni} \times \mathrm{vj})}{\mathrm{N} \times \mathrm{Z}} \times 100 \%$

Dimana: $\mathrm{I}=$ Intensitas serangan

ni $=$ Jumlah tanaman yang terserang dengan klasifikasi tertentu

$\mathrm{vj}=$ Nilai untuk klasifikasi tertentu

$\mathrm{Z}=$ Nilai tertinggi untuk klasifikasi

$\mathrm{N}=$ Jumlah tanaman seluruhnya dalam satu petak contoh

Penilaian intensitas serangan dibagi dalam beberapa kategori (Bower et al., 1995 dalam Winarto, 1997), yang telah dimodifikasi dan tersaji dalam tabel berikut.

Tabel(Table) 1. Klasifikasi tingkat kerusakan daun yang disebabkan oleh penyakit (Classification of leaves damage level caused by the disease)

\begin{tabular}{|c|l|c|l|}
\hline $\begin{array}{c}\text { Klasifikasi } \\
\text { (Classification) }\end{array}$ & $\begin{array}{c}\text { Kategori } \\
\text { (Category) }\end{array}$ & $\begin{array}{c}\text { Persentase serangan (\%) } \\
\text { (Attact presentage) }\end{array}$ & \multicolumn{1}{c|}{$\begin{array}{c}\text { Deskripsi } \\
\text { (Description) }\end{array}$} \\
\hline 0 & sehat & 0 & tidak ada serangan/daun sehat \\
\hline 1 & ringan & $1-21 \%$ & $\begin{array}{l}\text { daun yang rusak/terserang 1/5 dari } \\
\text { jumlah seluruh daun }\end{array}$ \\
\hline 2 & sedang & $21-40 \%$ & $\begin{array}{l}\text { daun yang rusak/terserang } 2 / 5 \text { dari } \\
\text { jumlah seluruh daun }\end{array}$ \\
\hline 3 & agak berat & $41-60 \%$ & $\begin{array}{l}\text { daun yang rusak/terserang } 3 / 5 \text { dari } \\
\text { jumlah seluruh daun }\end{array}$ \\
\hline 4 & berat & $61-80 \%$ & $\begin{array}{l}\text { daun yang rusak/terserang } 4 / 5 \text { dari } \\
\text { jumlah seluruh daun }\end{array}$ \\
\hline 5 & sangat berat & $>80 \%$ & $\begin{array}{l}\text { daun yang rusak/terserang }>80 \% \text { dari } \\
\text { jumlah seluruh daun }\end{array}$ \\
\hline
\end{tabular}

3. Identifikasi Penyakit

Material atau daun yang terserang penyakit diidentifikasi di laboratorium Klinik Tanaman, Departemen Proteksi Tanaman, Fakultas Pertanian, IPB. Daun jelutung yang terserang penyakit diletakkan pada media PDA steril dalam cawan petri kemudian diinkubasikan pada suhu kamar $\left(27^{\circ} \mathrm{C}\right)$. Selanjutnya dibuat pembiakan massal yang akan dipergunakan untuk uji Postulat Koch. Identifikasi cendawan dilakukan dengan memperhatikan ciri-ciri makroskopis dan mikroskopis. Ciri-ciri yang diperoleh kemudian dibandingkan dan dicocokkan dengan ciri-ciri yang disebutkan dalam buku Illustrated Genera of Imperfect Fungi Fourth Edition (1987).

\section{HASIL DAN PEMBAHASAN}

\section{A. Inventarisasi dan Identifikasi Penyakit}

Hasil pengamatan menunjukkan bahwa jenis penyakit yang menyerang bibit jelutung adalah bercak daun. Gejala awal serangan penyakit adalah pada permukaan daun terdapat bercak-bercak klorosis berwarna kuning kecoklatan berbentuk bulat. Pada perkembangan selanjutnya warna bercak menjadi coklat tua agak kemerah-merahan, kering dan melebar (Gambar 1), sehingga pada akhirnya 
seluruh daun dipenuhi oleh bercak dan daun menjadi kering dan rontok. Gejala serangan umumnya dimulai dari daun-daun yang lebih tua, kemudian ke beberapa daun yang lebih muda dan selanjutnya patogen menyebar ke seluruh daun. Apabila serangan berat, maka berangsur-angsur batang tanaman menjadi kering. Adanya serangan penyakit ini akan menganggu proses fotosintesis pada daun, yang dibuktikan dengan adanya daerah yang mati (nekrosis) berupa bercak klorosis.

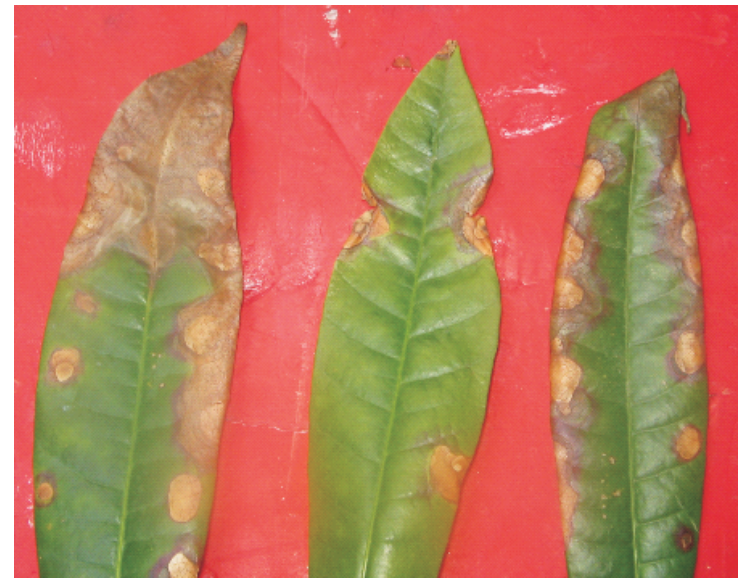

Gambar (Figure) 1. Gejala serangan Pyrenochaeta sp. pada daun jelutung (Symption of Pyrenochaeta sp. attact on jelutung leave)

Dari hasil identifikasi diketahui bahwa penyakit bercak daun disebabkan oleh patogen yaitu cendawan Pyrenochaeta sp. Cendawan ini termasuk dalam phyllum Ascomycota, kelas Euascomycetes, ordo Dothideales, famili Lophiostomataceae dan genus Pyrenochaeta. Pyrenochaeta sp. merupakan patogen yang menyerang banyak tanaman dan diantaranya ada pula yang spesifik dapat menyebabkan infeksi pada manusia. Genus Pyrenochaeta ini terdiri dari 3 spesies yang aktif, yaitu P. mackinnonii, $P$. unguishominis dan P. romeroi. Ketiga jenis tersebut dapat dibedakan dari warna, tesktur dan sifat koloninya.

Secara makroskopis, koloni Pyrenochaeta sp. mempunyai pertumbuhan agak cepat, datar dan kasar sampai lembut. Bagian depan intinya berwarna putih dan lama kelamaan menjadi kehijauan sampai kelabu, sedangkan bagian belakang berwarna hitam (Gambar 2a dan 2b). Secara mikroskopis, Pyrenochaeta sp. mempunyai septa, hifa hialin sampai subhialin, piknidia dan konidia. Piknidia berbentuk bola sampai berbentuk botol dan ostiolate (Gambar 3). Tubuh buah berbentuk bundar atau berbentuk botol yang mengandung konidia. Piknidia berwarna coklat sampai hitam dan mempunyai seta (rambut kaku) yang muncul dari bagian atasnya. Philia muncul dari piknidia. Konidia berukuran 2-4 x 1-2 $\mu \mathrm{m}$, terdiri dari $1 \mathrm{sel}$, berbentuk oval sampai silinder, hialin dan lurus atau ramping.

a

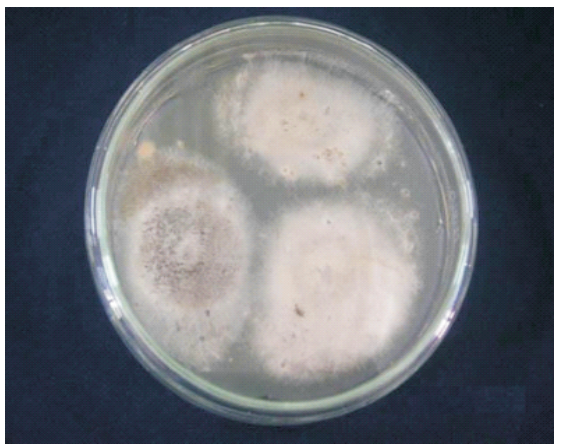

$\mathrm{b}$

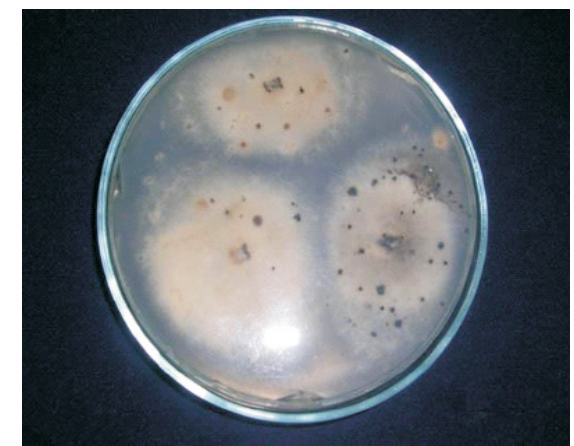

Gambar(Figure) 2. Koloni Pyrenochaeta sp.di media PDA(Colony of Pyrenochaeta sp.) (Foto: Widodo) a) dari pandangan atas (upper side) b) dari pandangan bawah (down side) 


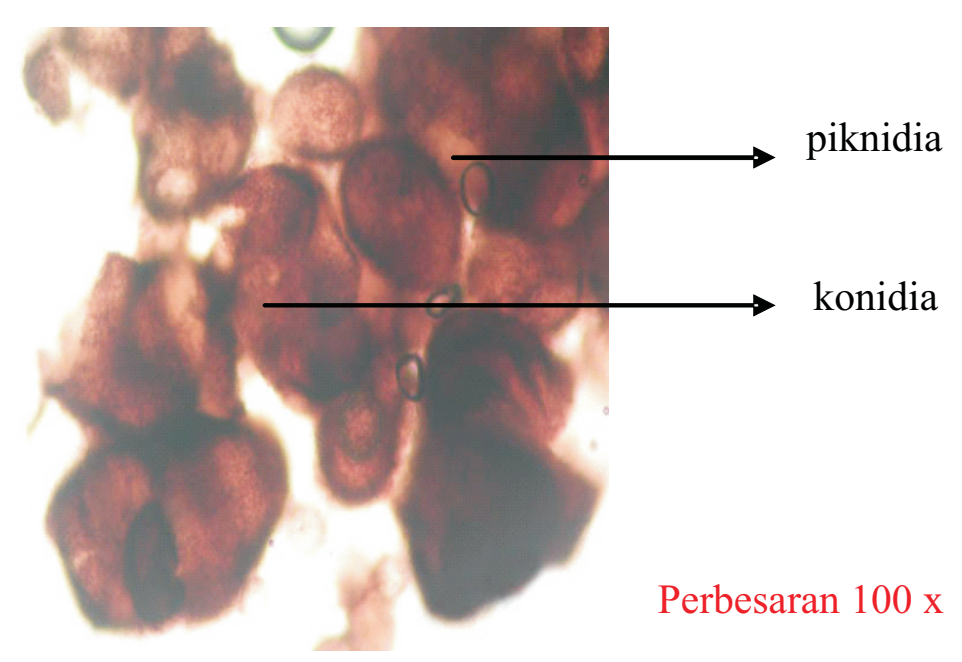

Gambar (Figure) 3. Piknidium Pyrenochaeta sp. (Picnidium of Pyrenochaeta sp.) (Foto : Widodo)

Informasi penyakit yang disebabkan oleh Pyrenochaeta sp. pada tanaman hutan belum banyak diketahui, namun cendawan ini menyebabkan penyakit penting pada tanaman pertanian karena dapat menghambat pertumbuhan tanaman dan menurunkan produksi. Seperti yang dilaporkan oleh Semangun (1991), pada beberapa daerah di Indonesia ditemukan adanya serangan penyakit akar merah jambu pada tanaman bawang yang disebabkan oleh Pyrenochaeta terrestris Hans, di daerah Pacet (Cianjur, Jawa Barat) dan Tegal (Jawa Tengah).

\section{B. Persentase dan Intensitas Serangan Penyakit serta Faktor-faktor yang Berpengaruh}

Besarnya persentase dan intensitas serangan penyakit masing-masing sebesar 35,95\% dan 9,34\% masih dikategorikan serangan ringan, akan tetapi apabila serangan penyakit tersebut tidak dicegah dan dikendalikan secara dini dapat meningkatkan sebaran penyakit dan kerusakan yang diakibatkannya.

Adapun faktor-faktor yang mempengaruhi serangan penyakit bercak daun yaitu :

1. Faktor internal tanaman/inang

Faktor internal tanaman meliputi benih dan vigor bibit, mempunyai pengaruh terhadap timbul dan berkembangnya penyakit. Pyrenochaeta sp. merupakan jenis patogen yang bisa terbawa oleh benih (seed borne). Diduga benih jelutung yang digunakan dalam pembibitan ini sudah terinfeksi oleh Pyrenochaeta sp. Secara visual sulit untuk mendeteksi spora/konidia Pyrenochaeta sp. pada benih jelutung yang terinfeksi, tetapi ketika bibit berumur 2 bulan sudah nampak gejala awal bercak daun. Benih jelutung bersifat rekalsitran dimana kadar air benih tidak dapat diturunkan bila kadar air benih masih tinggi. Diduga hal tersebut mendukung patogen untuk hidup dan menginfeksi benih.

\section{Faktor eksternal}

Faktor eksternal yang kemungkinan mendukung timbul dan berkembangnya penyakit adalah lingkungan fisik, seperti suhu, kelembaban udara dan curah hujan. Suhu sangat berpengaruh pada perkembangan patogen. Suhu optimum yang diperlukan untuk sporulasi Pyrenochaeta lycopersici yaitu $20-24^{\circ} \mathrm{C}$ (McGrath \& Campbell, 1983). Suhu di lokasi penelitian rata-rata berkisar $23-28^{\circ} \mathrm{C}$ dengan kelembaban relatif antara 70\% - 80\%. Menurut Agrios (1996), pada suhu optimum patogen menjadi sangat aktif, walaupun tanaman inang juga dalam keadaan optimum. Suhu yang lebih tinggi dari suhu optimal untuk pertumbuhan tanaman dapat merangsang pertumbuhan tanaman, tetapi meningkatkan resiko terhadap serangan penyakit. Hal ini berarti bahwa suhu di persemaian mendukung timbul dan berkembangnya patogen. 
Patogen dari kelompok cendawan memerlukan kelembaban yang cukup untuk menghasilkan dan mempertahankan spora/konidia dalam keadaan hidup, khususnya terhadap perkecambahan spora yang membutuhkan lapisan air yang menutupi jaringan untuk berkecambah. Pada banyak jenis cendawan, kelembaban juga mempengaruhi pelepasan spora/konidia dari sporofor/konidiofor (Agrios, 1996). Konidia Pyrenochaeta sp. memerlukan kelembaban tinggi untuk berkecambah. Kelembaban di lingkungan persemaian diduga mempengaruhi berkembangnya patogen dan penyakit. Selanjutnya curah hujan juga mempengaruhi perkembangan patogen dan penyakit. Curah hujan selama penelitian berkisar antara $2.000-3.000 \mathrm{~mm} /$ tahun dengan curah hujan per hari sebesar $8,22 \mathrm{~mm} /$ hari (6 hari/bulan) (Stasiun Klimatologi BMG Palembang, 2006). Selanjutnya Sinclair (1989) melaporkan bahwa curah hujan dan kelembaban yang tinggi mendukung berkembangnya penyakit. Penelitian lebih lanjut mengenai suhu, kelembaban dan curah hujan optimum yang mendukung timbul dan berkembangnya penyakit perlu dilakukan karena terkait dengan tindakan pencegahan dan pengendalian.

\section{Teknik silvikultur}

Teknik silvikultur secara tidak langsung dapat mempengaruhi timbulnya penyakit. Media tanam yang digunakan dalam pembibitan ini adalah campuran top soil dan pupuk kandang. Karena top soil dan pupuk kandang yang digunakan tidak disterilisasi terlebih dahulu, maka peluang munculnya patogen di akar semakin besar dan mengakibatkan resistensi inang menurun sehingga tanaman inang akan lebih mudah terinfeksi patogen. Dalam pembibitan jelutung ini digunakan sistem genangan, yang dapat mempengaruhi timbulnya serangan patogen. Adanya penggenangan dapat meningkatkan kelembaban tanah dan menurunnya suhu tanah. Kondisi ini menyebabkan meningkatnya sukulensi tanaman. Tanaman yang mempunyai sukulensi tinggi memiliki kerentanan terhadap serangan patogen. Selain itu meningkatnya kelembaban mikro tersebut menstimulasi patogen (terutama cendawan) untuk berkembang.

\section{Upaya Pencegahan dan Pengendalian Penyakit}

Upaya pencegahan timbulnya penyakit bercak daun yang bisa dilakukan dimulai dari penggunaan benih yang sehat. Benih yang akan disemai harus disterilisasi terlebih dahulu untuk mencegah infeksi patogen yang bersifat seed borne. Selain itu media tanam juga harus disterilisasi untuk mencegah tumbuhnya mikroorganisme termasuk patogen yang bisa terbawa tanah (soil borne). Sistem penggenangan yang diterapkan harus diatur untuk mencegah timbulnya patogen. Faktor lingkungan fisik seperti suhu dan kelembaban perlu diperhatikan sehingga bisa diantisipasi perkembangan patogen dan penyakit.

Dalam penelitian ini teknik pengendalian yang dilakukan adalah dengan aplikasi fungisida Dithane. Penggunaan Dithane cukup mampu menekan perkembangan dan pnyebaran penyakit. Saat ini belum banyak dilaporkan teknik pencegahan dan pengendalian penyakit bercak daun, yang disebabkan oleh Pyrenochaeta sp., yang efisien dan efektif. Oleh karena itu penelitian lebih lanjut mengenai teknik pencegahan dan pengendaliannya perlu dilakukan.

\section{KESIMPULAN DAN SARAN}

\section{A. Kesimpulan}

Dari hasil pengamatan terhadap serangan penyakit pada bibit jelutung di pembibitan disimpulkan bahwa :

1. Jenis penyakit yang menyerang bibit jelutung (Dyera costulata Hook.f) adalah bercak daun yang disebabkan oleh patogen cendawan Pyrenochaeta sp. 
2. Serangan penyakit pada bibit jelutung masih dalam kategori serangan ringan tetapi perlu diantisipasi perkembangan dan penyebarannya untuk menjamin keberhasilan pembibitan.

\section{B. Saran}

Perlu dilakukan penelitian mengenai faktor lingkungan fisik yang mempengaruhi serangan penyakit dan teknik pencegahan serta pengendalian penyakit pada bibit jelutung yang efektif dan efisien.

\section{UCAPAN TERIMA KASIH}

Penulis mengucapkan terima kasih kepada Dr. Ir. Widodo dan Ita Novrita yang telah membantu dalam melakukan identifikasi penyakit serta Nanang Herdiana, S.Hut atas saran dan masukannya.

\section{DAFTAR PUSTAKA}

Agrios, G.N. 1996. Ilmu Penyakit Tumbuhan Edisi 3 (Terjemahan). Gadjah Mada University Press. Yogyakarta.

Anonim. 1995. A Guide and Strategy for Their Conservation. IUCN Publications Unit. Vol 2. Cambridge. UK. Website http://www.unep-wcmc.org. Diakses pada tanggal 29 Juni 2007.

Barnett, H.I., B.B. Hunter. 1987. Illustrated Genera of Imperfect Fungi. Fourth Edition. MacMillan Publishing Company. New York.

Dinas Pertanian Kabupaten Musi Rawas. 2006. Rekapitulasi Data Curah Hujan Kabupaten Musi Rawas. Lubuk Linggau.

Lemmens, R.H.M.J., I. Soerianegara, W.C. Wong. (Eds.). 1995. Plant Resources of South East Asia (PROSEA) 5(2) Timber trees: Minor commercial timbers. Backhys Publishers. Leiden 655pp. Website http://www.unep-wcmc.org. Diakses pada tanggal 29 Juni 2007.

McGrath, D.M., R.N. Campbell. 1983. Improved Methods for Inducing Sporulation of Pyrenochaeta lycopersici. Plant Disease Vol. 67 No. 11 pp 1245-1248. Website http://www.md.csa.com. Diakses pada tanggal 1 Juli 2007.

Semangun, H. 1991. Penyakit-penyakit Tanaman Perkebunan di Indonesia. Gadjah Mada University Press. Yogyakarta.

Siahaan H, Nasrun, S. Islam, J. Muara. 2005. Teknologi Penanganan Benih. Laporan Hasil Penelitian. Balai Penelitian dan Pengembangan Hutan Tanaman. Palembang.

Sinclair, J.B. 1989. Threats to Soybean Production in the Tropics: Red leaf blotch and leaf rust. Department of Plant Pathology. University of Illinois at Urbana. Website http://www.apsnet.org. Diakses pada tanggal 1 Juli 2007.

Stasiun Klimatologi, Badan Meteorologi dan Geofisika Palembang. 2006. Rekapitulasi Data Curah Hujan Kota Palembang, Sumatera Selatan. Palembang.

Suharti, M. 1995. Penyakit Bercak Daun Eucalyptus deglupta di BKPH Cimanggu, Bandung Selatan. Buletin Penelitian Hutan No. 577. Pusat Penelitian dan Pengembangan Hutan dan Konservasi Alam. Bogor. 
Winarto, B. 1997. Studi keragaman gejala, morfologi, patogenitas, dan intensitas penyakit Diplocarpon rosae pada mawar. Prosiding Kongres Nasional dan Seminar Ilmiah Perhimpunan Fitopatologi Indonesia. Palembang, 27 - 29 Oktober 1997. Palembang. 